\title{
Relationship between Test Anxiety and Learning Styles of Architecture Undergraduates
}

\author{
Gülden Gümüşburun Ayalp*, Neslihan Özdemir \\ Architecture Department, Architecture and Design Faculty, Zirve University, Gaziantep, Turkey \\ Email: *gldngumusburun@hotmail.com
}

Received 19 January 2016; accepted 24 February 2016; published 29 February 2016

Copyright (C) 2016 by authors and Scientific Research Publishing Inc.

This work is licensed under the Creative Commons Attribution International License (CC BY).

http://creativecommons.org/licenses/by/4.0/

(c) (i) Open Access

\begin{abstract}
Learning which starts with birth of human being and continues for a lifelong varies from person to person. It is known that learning style differences is an important factor that affects students' success which is evaluated by examinations. If a student has high level of test anxiety, he will not get a good grade by choosing wrong answer because of his anxiety and he cannot show expected success level. The most important factor for increasing the success of architecture students who have different learning styles and different level of test anxiety is educating students by finding out differences at their learning styles and level of test anxiety. Therefore, this study aims to determine architecture students' level of test anxiety and their learning styles. In addition, it is aimed to find out the relationship between learning styles and test anxiety. Besides, the relationship between architecture students' level of test anxiety and some particular demographical properties (gender, age) are examined. With this context, data were collected from 347 architecture students from Gaziantep University, Zirve University and Hasan Kalyoncu University in 2015-2016 academic year. Learning style Inventory (LSI II) and Test Anxiety Inventory (TAI) were used as an instrument for collecting the data. Percentage and frequency tests, crosstabs and Chi-Square hypothesis tests were performed by using SPSS 17 software. As a conclusion of this study, it is determined that there is a significant relationship between learning styles of architecture students and their test anxiety level.
\end{abstract}

\section{Keywords}

Learning Style Inventory (LSI II), Architectural Education, Test Anxiety Inventory (TAI)

\footnotetext{
*Corresponding author.
} 


\section{Introduction}

Education is vital for every country in the world and effective education can help boost the development of the country. Learning is an inseparable part of education. Each person is unique, with his/her own characteristics, abilities, preferences, and ways of thinking and acting that make them different from each other (Kuri \& Truzzi, 2002). Preferred ways of perception, organization, and retention of new information are distinctive and consistent for each learner (Chou and Wang 2000; Hsu 1999). The particular method of perceiving and processing information is denominated as a learning style (Carter et al., 2000). People have different learning styles that are reflected in different academic strengths, weaknesses, skills, and interests (Felder et al. 2002). Given the almost unlimited variety of job descriptions within architecture, it is safe to assume that students with every possible learning style have the potential to succeed as architects. Numerous reports on the application of learning styles in architecture education found in the pertinent literature clearly show that the benefits of its implementation are significant. Therefore, architecture syllabi and the programs of other disciplines should be prepared with consideration for the learning styles of students.

As testing is a common practice in contemporary society for making important decisions about an individual's status in school, college, and work (Lowe et al. 2008; Zeidner, 1998), it is no wonder that test anxiety is a significant educational problem affecting many of students in schools and colleges. Many students face different situations of anxiety during their examinations. Students with test anxiety feel tense, fearful and worried in evaluative situations (Spielberger et al., 1979; Spielberger \& Vagg, 1995). Research relating test anxiety to academic performance has established that high levels of test anxiety are associated with lower levels of students' learning and performance (Sub \& Prabha, 2003). Often test anxious students at all levels of education perform more poorly on standardized tests (Everson et al, 1991) and receive poorer grades (Chapell et al., 2005) than they ought to because anxiety and other test taking deficiencies interfere with their performance, either directly or indirectly (Efklides et al., 1997, 1999; Lowe et al., 2008; Metallidou \& Vlachou, 2007).

In order to assess individual differences in test anxiety, Spielberger developed the Test Anxiety Inventory (TAI; Spielberger, 1980) which is a self-report instrument. The TAI is one of the most widely used of the test anxiety inventories as it has been translated or adapted for many populations (see Ware et al., 1990).

Spielberger had two major goals in developing the TAI: 1) to construct a brief, valid self-report measure of the test anxiety which was highly correlated with other measures of the construct and 2) to use factor analytic procedures to measure the emotionality and worry components of the test anxiety identified by Liebert and Morris (1967). Emotionality refers to perceived autonomic reactions (physiological arousal) evoked by evaluative stress (Spielberger \& Vagg, 1995), whereas worry refers to cognitive concerns about the consequences of failure (Liebert \& Morris, 1967). Worry tends to be associated with performance decrements on cognitive and intellectual tasks, but emotionality is not (see Hembree, 1988; Hong, 1998; Spielberger et al., 1979; Van der Ploeg, 1984). If a student has high level of test anxiety, he will not get a good grade by choosing wrong answer because of his anxiety and he cannot show desired success level. The most important factor for increasing the success of architecture students who have different learning styles and different level of test anxiety is educating students by finding out differences at their learning styles and level of test anxiety. Therefore, this study aims to focus on test anxiety in architecture education using Spielberger's Test Anxiety Inventory and explores the relationship between test anxiety and learning styles, gender, age, year of study, and type of university. Within the scope of the study, survey forms were collected from architecture students at three different universities in Turkey. SPSS 18 software was used in the analysis of data; percentage and frequency distributions were analyzed, and independent sample test and one-way ANOVA were examined. In addition, some proposals are brought forward.

\section{Literature Review}

Phillips et al. (1972) have described that anxiety is a response to different environmental factors. According to Sarason (1984), anxiety directly belongs to the emotions of human beings and it points out the lack of self-assurance. It may also be a kind of threat from the environment. Sarason (1984) refers to test anxiety as “A widely studied personality variable in part because it provides a measure of the personal salience of one important definable class of threating situations in which people are evaluated” (Sarason, 1984). According to Liepmann et al. (1992), test anxiety is always developed among students due to results of failure, and it is communicated through early interactions of judgments of parents of those students who are performing in the tests. Spielberger and Vagg (1995) have described that test anxiety is an element of general anxiety. According to them, "test an- 
xiety is composed of cognitive attention processes that interfere with performance in academic situations or examinations". (Spielberger \& Vagg, 1995). A very important definition of test anxiety is given by Zeidner (1998), "The set of phenomenological, physiological and behavioral responses that accompany concern about possible negative consequences or failure on the examination or similar evaluative situation".

The test anxiety construct is widely accepted to be multidimensional; consisting of the "worry" and "emotionality" components (Liebert \& Morris, 1967). Worry refers to the cognitive component of test anxiety, such as negative and derogatory self-statements related to failure. Emotionality refers to affective physiological component of test anxiety, the person's perception of autonomic arousal and tension. Worry and emotionality scores correlate to a high degree (Ware et al., 1990); however, they are elicited and maintained by different conditions. Worry is triggered by internal and external cues that focus on evaluative situations as threatening to one's esteem, whereas emotionality is triggered by the immediate external cues of the assessment situation itself (Eysenck, 1992). Individuals high in test anxiety have more structured and pervasive "worry clusters" in long-term memory, which include thoughts and images based on prior experiences of evaluative situations involving failure. These clusters predispose test anxious individuals to perceive assessment situations as more threatening and worry cognitions are more easily triggered.

The theory that everyone has a preference for a particular style of learning is now universally accepted by training and development specialists and managers alike. The most successful educational activities occur when the delivery method matches the learning preference of learner and learner completes the learning process. When the literature reviewed, various type of learning style models and theories can be encountered. Honey and Mumford (1989), Kolb (1984) are leading researchers at learning style theories. The concept of learning styles was first developed by David Kolb (1984), and the learning style model which was reproduced by Honey and Mumford, was a replica of Kolb's experiential learning theory (Rayner \& Riding, 1997). This is the reason of using the David Kolb's learning theory in this research. Kolb considered learning as a process and named as experiential learning theory. Experiential learning theory considers learning as a cycle that begins with experience, continues with reflection and later leads to action that becomes a concrete experience for reflection (Ashton, 2000; Kolb, 1984). Within the Kolb learning style, four learning modes are identified (see Figure 1). 1) concrete experience (CE); 2) reflective observation (RO); 3) abstract conceptualization (AC); and 4) active experimentation (AE).

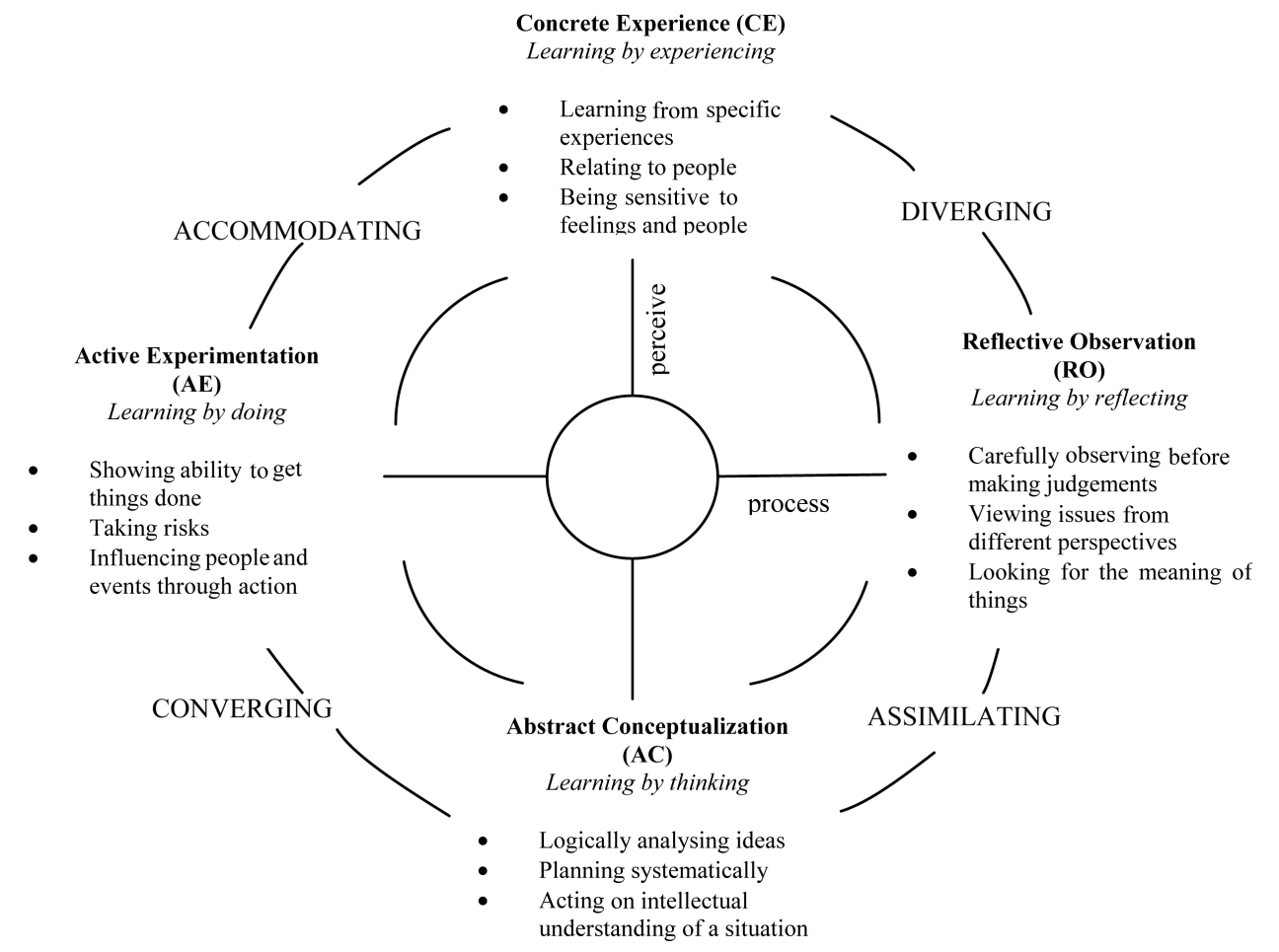

Figure 1. Four learning modes of experiential learning theory (Demirbaş, Demirkan 2003). 
“The concrete experience” mode describes people who feel more than they think. Individuals in this mode tend to be very good at relating to others and they tend to be intuitive decision-makers. "The reflective observation" mode describes people who would rather watch and observe others than are active participants. Individuals in this mode tend to appreciate exposure to differing points of view. "The abstract conceptualization" mode describes people who think more than they feel. Such people tend to have a scientific approach to problem solving as opposed to a more artistic approach. "The active experimentation” mode describes individuals who take an active role in influencing others as well as situations. These individuals welcome practical applications rather than reflective understanding as well as actively participating rather than observing.

Learning is a cycle and one learning style takes primacy for each individual according to experiential learning theory. Each person's learning style is a combination of two of these four learning modes (Jonassen \& Grobowski, 1999). Finally, learners can thus be classified into one of four learning styles, namely, converger, diverger, assimilator, and accommodator, mapped in one of the four quadrants (Kolb, 1985).

- Convergers combine AC and AE. Convergers are best at finding practical uses for theories and ideas and are good at solving problems and making decisions. Kolb suggests they prefer dealing with technical tasks rather than with social and interpersonal issues (Kolb \& Kolb, 2005).

- Divergers combine CE and RO. Divergers are best at viewing concrete situations from different points of view, they prefer brainstorming situations to taking action (Kolb \& Kolb, 2005). These types of learners are interested in people and tend to be imaginative and emotional (Smith \& Kolb, 1996). Diverging learners have the ability to synthesize and/or assimilate a wide-range of totally different observations into a comprehensive explanation that enables them to generate many ideas (Hsu, 1999).

- Assimilators are learners who combine AC and RO. Assimilators are best at understanding a wide range of information and organizing it into a concise, logical form. They are more interested in abstract ideas and concepts than people. They value the logical soundness of a theory more than its practical value (Kolb \& Kolb, 2005).

- Accommodators are learners who combine the learning steps of CE and AE. Accommodating learners grasp their environments concretely through their feelings and utilize action to transform the information obtained. Accommodators learn primarily from "hands-on" experience. They prefer to act on feelings rather than on logical analysis. In solving problems, they rely more heavily on people for information than on their own technical analysis (Hsu, 1999; Kolb \& Kolb, 2005).

In order for learning to be effective, learner must fully complete the cycle. This means being able to take action, to stand back and observe, to analyze these observations, and to apply these analyses in practical situations. However, the learning does not have to take place in this order. It is possible to start at any point on the cycle and still learn effectively, provided that every stage is completed.

\section{Architecture Education}

Architectural design covers a wide range of factors beyond the physical and structural aspects of buildings. A good architecture should reflect the life of the community in which it is located. Therefore architectural education is a multi-facetted field due to the complexity of the social and cultural aspect normally associated to it. Architectural education is not restricted to physical building design and also incorporates value system, philosophy, sustainability, technologies and other related areas. Diverse subjects other than Design Studio offered in any architecture courses reflect the complexities integral in architecture. Integration of these diverse subjects with the Design Studio is very important as the architecture course offered should be able to produce innovative, creative and holistic architects who are sensitive to the needs of the society, the environment and technology (Ibrahım \& Utaberta, 2012).

Nalçakan and Polatoğlu (2008) analyzed the curricula of architecture departments in Turkey, and they summarized the syllabus of six important architecture departments at Table 1.

When Table 1 analyzed, it is clearly seen that design courses constitute the spine of architecture education. Compared to other subjects in the architecture course, Design Studio is the most dominant subject with the highest credit hours per week. Other subjects such as Construction Technology, Architectural History and Theory, Environmental Physics, Design Communication and others have to serve Design Studio learning in each semester. It is known that design courses are non-mathematical courses and do not need test or examination for evaluating the success of student. Instead of a test, process evaluation is more important for these types of courses. 
Table 1. Analyze of six important architecture departments’ curricula in Turkey (Nalçakan \& Polatoğlu, 2008).

\begin{tabular}{|c|c|c|c|c|c|c|}
\hline $\begin{array}{c}\text { Universities } \\
\text { Hours and Credit of Courses }\end{array}$ & $\begin{array}{c}\text { Mimar Sinan } \\
\text { University }\end{array}$ & $\begin{array}{l}\text { İstanbul } \\
\text { Techical } \\
\text { University }\end{array}$ & $\begin{array}{c}\text { Yıldız } \\
\text { Technical } \\
\text { University }\end{array}$ & $\begin{array}{l}\text { Middle } \\
\text { East } \\
\text { Technical } \\
\text { University }\end{array}$ & $\begin{array}{c}\text { Dokuz Eylül } \\
\text { University }\end{array}$ & $\begin{array}{l}\text { Karadeniz } \\
\text { Technical } \\
\text { University }\end{array}$ \\
\hline Credit & 167 & 153 & 180 & 188 & 169 & 240 \\
\hline Hour & 194 & 198 & 224 & 243 & 197 & 200 \\
\hline Number of Course & 72 & 49 & 63 & 53 & 63 & 46 \\
\hline Credit of Design Course (number) & 48 & 38 & 46 & 56 & 42 & 46 \\
\hline Credit of Design Course (\%) & 28.74 & 24.88 & 25.56 & 29.79 & 24.85 & 31.67 \\
\hline Elective Course Credit & 26 & 27 & 20 & 30 & 10 & 26 \\
\hline Elective Course (hour) & 26 & 27 & 20 & 30 & 10 & 12 \\
\hline Credit of Architecture Theory & 16 & - & 8 & - & 8 & 4 \\
\hline Architecture Theory (hour) & 20 & - & 12 & - & 10 & 12 \\
\hline Construction Technology (hour) & 26 & 8 & 15 & - & 10 & 12 \\
\hline Credit of Construction Project & 6 & 5 & 6 & - & - & - \\
\hline Construction Project (hour) & 8 & 8 & 8 & - & - & - \\
\hline
\end{tabular}

\section{Research Method}

\subsection{Sample Selection}

The sample consisted of first, second, third and fourth-year architecture students during the 2015-2016 academic year from departments of architecture at Gaziantep University, Zirve University, Hasan Kalyoncu University in Turkey. Zirve University and Hasan Kalyoncu University are private universities. The participants were randomly selected. During the study, 347 items of data were collected.

\subsection{Instruments}

Three instruments were used to collect research data and these were: 1) Test Anxiety Inventory to measure test anxiety; 2) Learning Style Inventory (LSI II) to determine learning styles of architecture students and 3) the researcher constructed demographical questionnaire that collected bio-data (gender, age, etc.).

\subsubsection{Test Anxiety Inventory (TAI)}

The TAI is a self-report psychometric scale that was designed by Spielberger (1980) to "measure individual differences in test anxiety as a situation-specific personality trait". The TAI was developed for use with adolescents and adults and consists of 20 items that ask respondents to indicate how they generally feel in test situations by reporting the frequency that they experience specific symptoms of anxiety before, during and after examinations. According to Spielberger et al., (1978), the development of TAI was based on two goals. These goals were construction of a brief and self-report scale and the employment of factor analytic procedures for the measurement of Worry and Emotionality Subscales (Spielberger et al., 1978). According to Spielberger (1980), Test Anxiety Inventory is especially designed to measure the test anxiety of high school and college students. It contains three subscales: Test Anxiety-Total (TAI-T), Test Anxiety-Worry (TAI-W), and Test Anxiety-Emotionality (TAI-E). Eight items of Test Anxiety Inventory measure the TAI-W (3, 4, 5, 6, 7, 14, 17, 20), eight items measure TAI-E $(2,8,9,10,11,15,16,18)$ and the remaining four for measuring TAI-T. Test Anxiety Inventory is a 4-point Likert type scale and the students have to respond to the four options: 1) Almost Never, 2) Sometimes, 3) Often and 4) Almost Always. The reliability values of alpha coefficient for subscales of original version of Test Anxiety Inventory were: 0.96 for TAI-T, 0.91 for TAI-W and 0.91 for TAI-E (Spielberger, 1980). 


\subsubsection{Learning Style Inventory (LSI II)}

The Learning Style Inventory test is in the form of twelve open-ended questions that have four alternative responses. Each question asks respondents to rank order four sentence endings in a way that best describes their learning style. After answering all the questions, four scores are calculated according to the key of the test. These scores are clustered under four modes of the learning cycle: Concrete experience (CE), reflective observation (RO), abstract conceptualization (AC) and active experimentation (AE) (Kolb, 1984). After this process, the four scores are placed on the Cycle of Learning graph (Figure 2).

From this information, several kite shaped diagrams are formed and these determine the preferred learning style type of a particular respondent. This kite shape explains the relative preferences for the four phases of the learning cycle.

The combined scores explain which of the four determinant learning styles best describes the respondent. For this stage, the scores of four learning modes (AC, $\mathrm{CE}, \mathrm{AE}$, and $\mathrm{RO}$ ) are used in the formula below in order to obtain the two combination scores:

$$
\begin{aligned}
& (A C)-(C E)=(A C-C E) \\
& (A E)-(R O)=(A E-R O)
\end{aligned}
$$

Then, according to Kolb's theory (1999), the found scores are located on the Learning Style Type Grid and the learning styles of participants are established as accommodator, diverger, assimilator, or converger (Figure 3).

\subsubsection{Demographical Questionnaire}

Additional variables were measured using a purpose-designed questionnaire, "Demographical Questionnaire" for determining the student profile. The subjects of questions are the year of architecture education, gender, age, type of university and name of university. Type of university was measured in two categories: State and Private.

\subsection{Procedure}

Data were collected across multiple sessions ranging in size 402 participants face to face; however, 55 of questionnaire were out of measurement because of students' filling the survey incorrectly. Therefore, the response

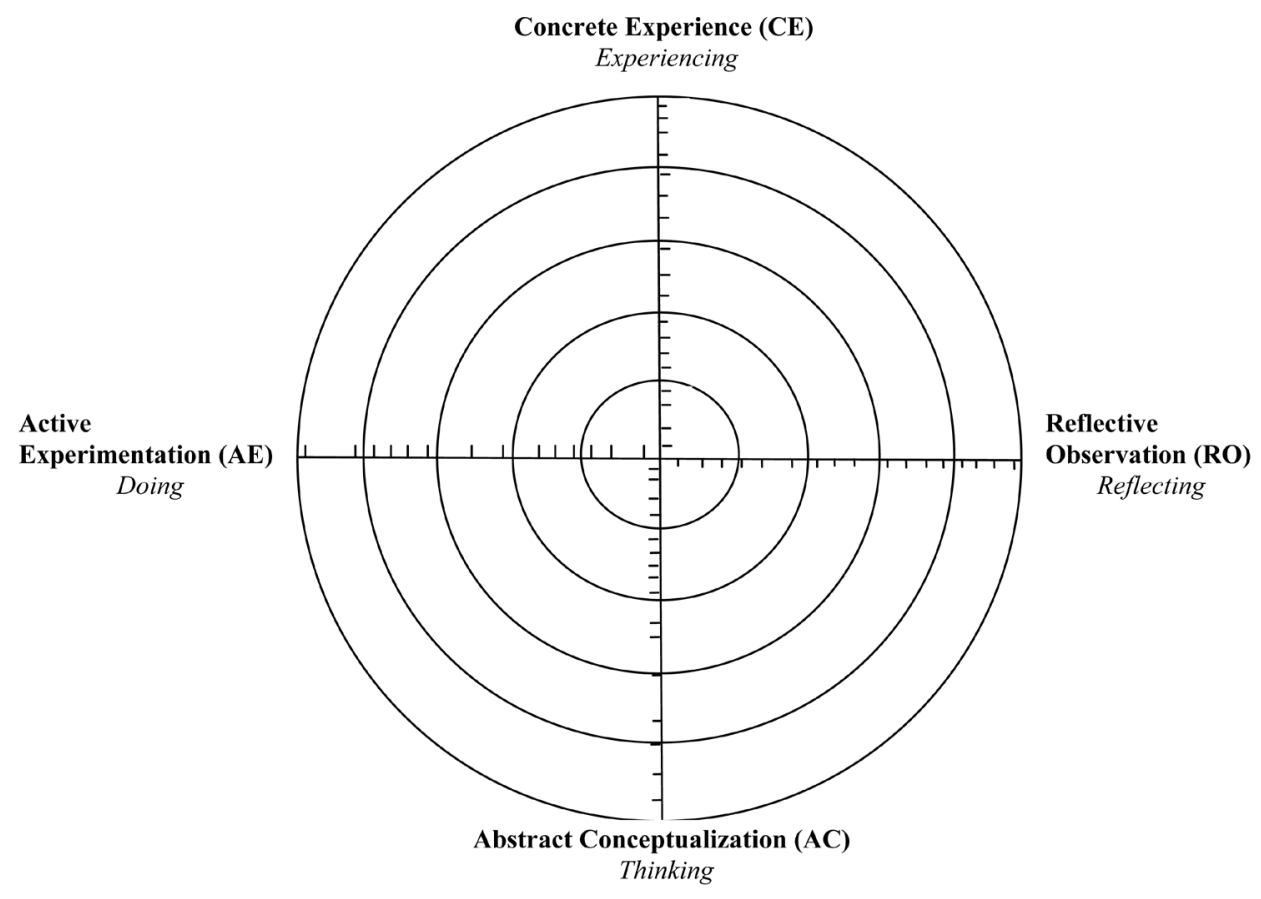

Figure 2. The cycle of learning (Kolb, 1999). 


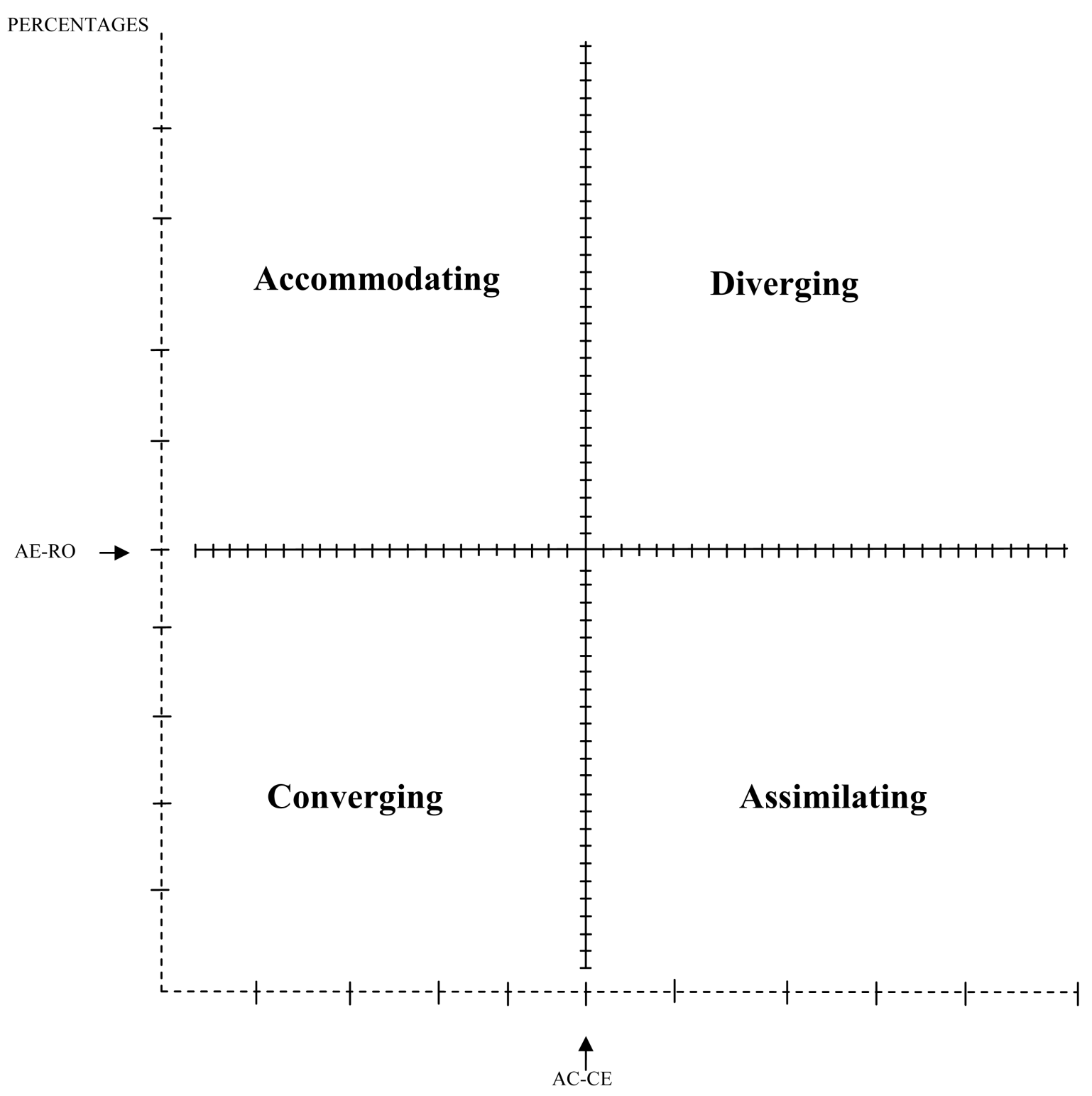

Figure 3. Learning style type grid (Kolb, 1999).

rate is $86.3 \%$ which is quite enough for continuing the research. The survey forms were applied the students between September-October 2015 at 2015-2016 academic year. Participation was voluntary basis. Freshmen, second, third and fourth year students were attended the research. The reason for applying the survey to students in all years was determining the learning styles and test anxiety of architecture students, and defining the changes in learning styles and test anxiety throughout architecture education.

\section{Findings}

\subsection{Participants}

The sample consisted of architecture students during the 2015-2016 academic year from departments of architecture at Zirve University, Gaziantep University, and Hasan Kalyoncu University in Turkey. The demographical characteristics of participants were shown at Table 2. The mean age of the 347 participants was 21.45 years old, with most $(46.7 \%+34.8 \%=81.5 \%)$ ranging in age from 20 to 23 years old; $217(62.5 \%)$ were female and $130(37.5 \%)$ were male. Most of the participants (229\% or $76.0 \%)$ were educated at private universities; 75 
Table 2. Participant characteristics.

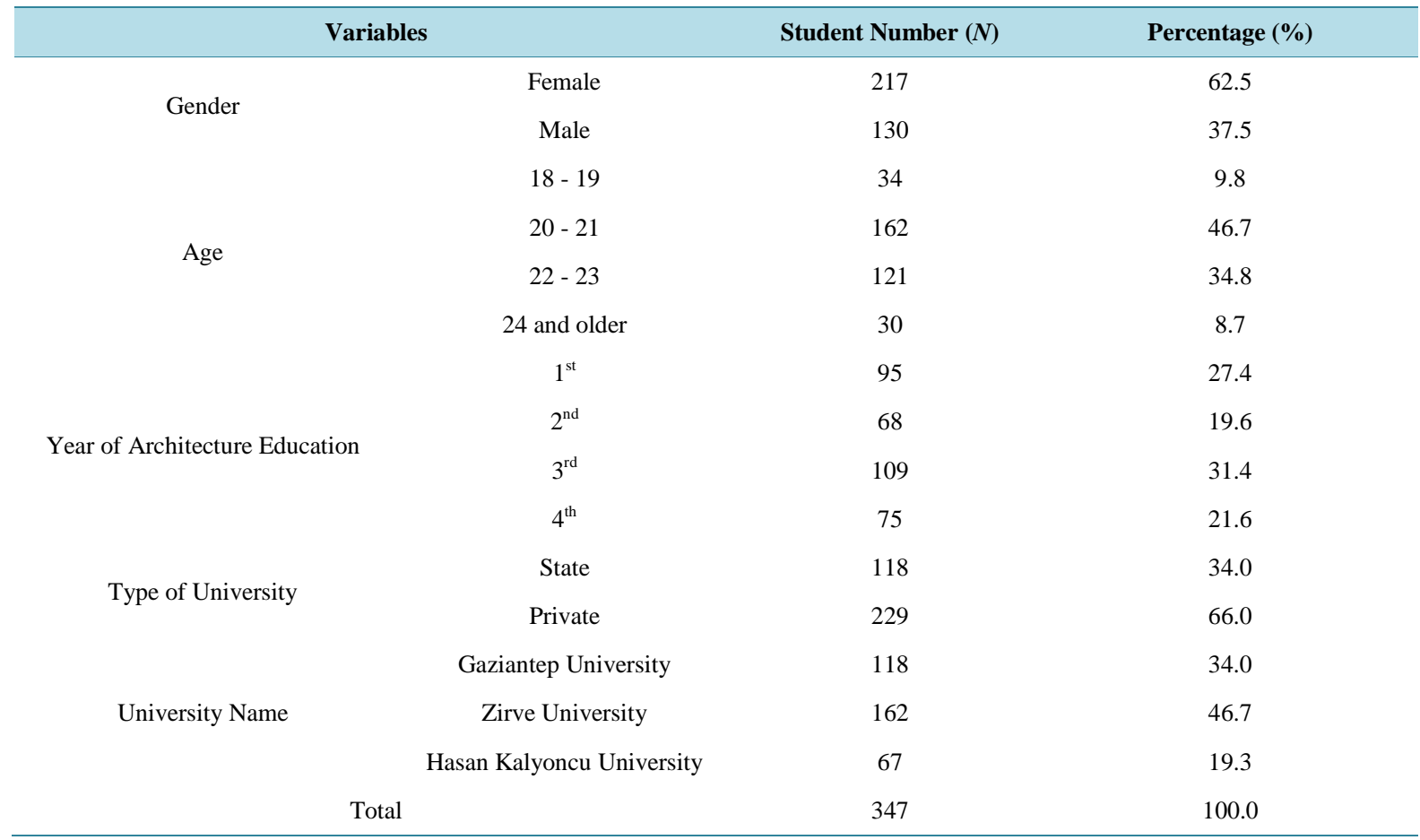

students (21.6\%) were fourth-year students, 109 (31.4\%) were third-year students, 68 (19.6\%) were second-year students, and 95 (27.4\%) were first-year students (Table 2).

\subsection{Descriptive Data and Hypothesis Tests}

The relationships between Test Anxiety scores and gender, type of university, year of architecture education, age and learning styles were examined under this section. For this purpose independent t-test, one-way ANOVA and chi-square tests were performed (Table 3 and Table 6).

Descriptive data for Test Anxiety Inventory (TAI) and component scores along with individual and group differences are shown in Table 3:

Female students reported higher test anxiety scores than male students. In addition to, independent t-test was performed to find out the relationship between gender and test anxiety and significant relationship was found for both sub-scales of TAI and total TAI ( $p=0.001<0.05 ; \mathrm{p}=0.000<0.05 ; \mathrm{p}=0.022<0.05$ ).

No differences were observed in the TAI data for type of university.

Minor differences were apparent in the TAI data for year of architecture education; students from fourth year students reported lower scores than the three remaining groups.

Students at the age of 18 - 19 reported higher TAI scores than the other three groups. In addition to, when one-way ANOVA was performed for finding out the relationship between TAI scores and age of students, it is observed that there is significant relationship between TAI-Emotionality, TAI total and students' age $(\mathrm{p}=0.034<$ 0.05 and $\mathrm{p}=0.047<0.05$ ). Tukey tests were performed to find out the source of differences (Table 4 and Table 5). The source of difference at TAI-Emotionality and total TAI scores originated from the students at the age of $18-19$ and 24 years old and older ones $(p=0.024<0.05$ and $p=0.026<0.05)$. In the other words, students at the age of 18 - 19 have higher scores than 24 years old older ones.

The results of Chi-square test which was conducted for determine the relationship between test anxiety and learning styles of architecture students are shown in Table 6. It is reported that there are significant relationship between learning styles and test anxiety worry and emotionality and total scores of architecture students ( $\mathrm{p}=$ $0.035<0.05 ; \mathrm{p}=0.045<0.05$ and $\mathrm{p}=0.024<0.05)$. In addition,

- Most of architecture students have low scores on test anxiety.

- Majority of students' learning style is accommodator. This result shows parallelism with Kob’s study result. 
Table 3. Descriptive data and hypothesis tests for test anxiety of architecture students.

\begin{tabular}{|c|c|c|c|c|c|c|c|c|c|c|}
\hline \multirow{3}{*}{\multicolumn{2}{|c|}{ Variables }} & \multicolumn{9}{|c|}{ Test Anxiety Inventory } \\
\hline & & \multicolumn{3}{|c|}{ TAI-Worry } & \multicolumn{3}{|c|}{ TAI-Emotionality } & \multicolumn{3}{|c|}{ TAI-Total } \\
\hline & & $\bar{X}$ & $\mathrm{SD}$ & $\mathrm{p}$ & $\bar{X}$ & $\mathrm{SD}$ & $\mathrm{p}$ & $\bar{X}$ & SD & $\mathrm{p}$ \\
\hline \multirow{2}{*}{ Gender } & Female & 17.17 & 4.68 & \multirow{2}{*}{0.001} & 18.83 & 5.25 & \multirow{2}{*}{0.000} & 45.08 & 11.61 & \multirow{2}{*}{0.022} \\
\hline & Male & 15.56 & 4.35 & & 16.52 & 4.63 & & 39.93 & 10.10 & \\
\hline \multirow{3}{*}{$\begin{array}{c}\text { Type of } \\
\text { University }\end{array}$} & State & 16.78 & 4.01 & \multirow{2}{*}{0.541} & 18.42 & 4.51 & \multirow{2}{*}{0.240} & 43.99 & 9.85 & \multirow{2}{*}{0.873} \\
\hline & Private & 16.46 & 4.91 & & 17.73 & 5.43 & & 42.72 & 12.07 & \\
\hline & $1^{\mathrm{st}}$ & 16.97 & 4.68 & & 18.72 & 5.36 & & 44.41 & 11.63 & \multirow{4}{*}{0.316} \\
\hline \multirow{3}{*}{$\begin{array}{c}\text { Year of } \\
\text { Architecture } \\
\text { Education }\end{array}$} & $2^{\text {nd }}$ & 16.25 & 4.61 & \multirow{3}{*}{0.257} & 17.66 & 5.23 & & 42.19 & 10.96 & \\
\hline & $3^{\text {rd }}$ & 16.96 & 4.80 & & 18.16 & 4.96 & 0.168 & 43.89 & 11.96 & \\
\hline & $4^{\text {th }}$ & 15.77 & 4.24 & & 17.00 & 4.95 & & 41.34 & 10.37 & \\
\hline \multirow{4}{*}{ Age } & $18-19$ & 18.26 & 5.18 & \multirow{4}{*}{0.070} & 19.47 & 6.04 & \multirow{4}{*}{0.034} & 46.91 & 12.80 & \multirow{4}{*}{0.047} \\
\hline & $20-21$ & 16.47 & 4.57 & & 18.20 & 5.18 & & 43.30 & 11.53 & \\
\hline & $22-23$ & 16.55 & 4.29 & & 17.75 & 4.48 & & 42.93 & 10.17 & \\
\hline & 24 and older & 15.27 & 5.17 & & 15.83 & 5.80 & & 38.93 & 12.37 & \\
\hline
\end{tabular}

Table 4. Tukey test for TAI-Emotionality score and age.

\begin{tabular}{cccc}
\hline Age $(\mathbf{i})$ & Age $(\boldsymbol{j})$ & Mean Difference $\left(\bar{X}_{i}-\bar{X}_{j}\right)$ & Significance (p) \\
\hline \multirow{2}{*}{$18-19$} & $20-21$ & 1.273 & 0.549 \\
& $22-23$ & 1.719 & 0.307 \\
& 24 and older & $\mathbf{3 . 6 3 7 ^ { * }}$ & $\mathbf{0 . 0 2 4}^{*}$ \\
$20-21$ & $18-19$ & -1.273 & 0.549 \\
& $22-23$ & 0.445 & 0.886 \\
& 24 and older & 2.364 & 0.093 \\
& $18-19$ & -1.719 & 0.307 \\
& $20-21$ & -0.445 & 0.886 \\
\hline
\end{tabular}

*The mean difference is significant at the 0.05 level.

\section{Table 5. Tukey test for TAI-Total score and age.}

\begin{tabular}{cccc}
\hline Age $(\mathbf{i})$ & Age $(\mathbf{j})$ & Mean Difference $\left(\bar{X}_{i}-\bar{X}_{j}\right)$ & Significance (p) \\
\hline \multirow{2}{*}{$18-19$} & $20-21$ & 3.603 & 0.329 \\
& $22-23$ & 3.977 & 0.268 \\
& 24 and older & $\mathbf{0 . 0 2 6}$ \\
$20-21$ & $18-19$ & -3.603 & 0.329 \\
& $22-23$ & 0.374 & 0.993 \\
$22-23$ & 24 and older & 4.375 & 0.209 \\
& $18-19$ & -3.977 & 0.268 \\
\hline
\end{tabular}

\footnotetext{
${ }^{*}$ The mean difference is significant at the 0.05 level.
} 
Table 6. Relationship between TAI scores and learning styles.

\begin{tabular}{|c|c|c|c|c|c|c|c|c|c|c|c|c|}
\hline \multirow{3}{*}{ TAI } & \multirow{3}{*}{$\begin{array}{c}\text { Amount } \\
\text { of } \\
\text { Anxiety }\end{array}$} & \multicolumn{8}{|c|}{ Learning Styles } & \multirow{3}{*}{\multicolumn{2}{|c|}{ Total }} & \multirow{3}{*}{$\mathbf{p}$} \\
\hline & & \multicolumn{2}{|c|}{ Accommodator } & \multicolumn{2}{|c|}{ Converger } & \multicolumn{2}{|c|}{ Diverger } & \multicolumn{2}{|c|}{ Assimilator } & & & \\
\hline & & $\mathrm{f}$ & $\%$ & $f$ & $\%$ & $\mathrm{f}$ & $\%$ & $\mathrm{f}$ & $\%$ & & & \\
\hline \multirow{2}{*}{ TAI-Worry } & Low & 92 & 73,6 & 74 & 85.0 & 50 & 65.7 & 46 & 77.9 & 262 & 75.5 & \multirow{2}{*}{0.030} \\
\hline & High & 33 & 24.6 & 13 & 15.0 & 26 & 34.3 & 13 & 22.1 & 85 & 25.5 & \\
\hline \multirow{2}{*}{ TAI-Emotionality } & Low & 86 & 68.8 & 67 & 77.0 & 43 & 56.5 & 38 & 64.4 & 234 & 67.4 & \multirow{2}{*}{0.045} \\
\hline & High & 39 & 31.2 & 20 & 23.0 & 33 & 43.5 & 21 & 35.6 & 113 & 32.6 & \\
\hline \multirow{2}{*}{ TAI-Total } & Low & 90 & 72.0 & 72 & 82.7 & 47 & 61.8 & 45 & 76.2 & 254 & 73.1 & \multirow{2}{*}{0.024} \\
\hline & High & 35 & 28.0 & 15 & 17.3 & 29 & 31.2 & 14 & 23.8 & 93 & 26.9 & \\
\hline
\end{tabular}

However, some researchers who searched the learning styles of architecture students found out the learning styles of students as assimilator (Gumusburun Ayalp, Senyigit, \& Erman, 2015; Demirbaş \& Demirkan, 2007; Tucker, 2008; Kvan \& Yunyan, 2005).

- Diverger students' test anxiety at worry subscale is higher and much more than that of the converger ones.

- Similarly, diverger students' test anxiety at emotionality subscale is higher than, almost double, that of converger students.

\section{Results and Discussion}

Students' individual learning styles and test anxiety level can play a vital role in the learning and education process. In this regard, understanding the learning style differences and defining the level of test anxiety is an important step enhancing success for architecture students. The obtained results of this research present that female architecture students have higher scores at test anxiety than the male ones. Gender differences in test anxiety have been reported as a robust finding with female students reporting a higher level of test anxiety than male students (Hembree, 1988; Zeidner, 1998). Several studies have noted that gender differences in test anxiety are larger for the emotionality component of test anxiety (e.g. Zeidner, 1990; Zeidner \& Schleyer, 1999). The results of these studies support this research finding.

Age differences in test anxiety are another finding of the present study. Younger architecture students have higher test anxiety than the older ones.

Differences at year of architecture education do not affect the test anxiety of students. There is infinitesimal difference between the forth year students and other ones.

Most of the architecture students have low scores of test anxiety. When the previous studies are examined, it is reported that students have lower test anxiety scores at non-mathematical courses than the mathematical ones (Richardson \& Suinn, 1972). Therefore, the result of previous studies supports this finding.

Finally, learning style differences of architecture students in test anxiety is an attractive finding of this research. Most of the converger students have low scores at all subscales of test anxiety, whereas divergers have the highest scores. In addition, no matter what the learning styles of students have, test anxiety-emotionality is higher than test anxiety-worry. Based on the findings from the present study, if an architecture student especially a diverger one cope with his emotionality test anxiety, his academic success will increase, in other words, coaching students in the effective use of learning styles that are empirically proved by research to be useful might be beneficial in reducing test anxiety.

\section{References}

Ashton, P. (2000). Collective Action for Design Learning-Social Interaction Analysis in the Design School Studio. In S. Scrivener, L. Ball, \& A. Woodcock, Eds., Collaborative Design (pp. 513-524). London: Springer. http://dx.doi.org/10.1007/978-1-4471-0779-8_48

Carter, C., Bishop, J., \& Kravits, S. L. (2000). Keys to Effective Learning (2nd ed.). Upper Saddle River, NJ: Prentice Hall.

Chapell, M. S., Blanding, Z. B., Silverstein, M. E., Takahashi, M., Newman, B., Gubi, A., \& McCann, N. (2005). Test Anxiety and Academic Performance in Undergraduate and Graduate Students. Journal of Educational Psychology, 97, 268- 
274. http://dx.doi.org/10.1037/0022-0663.97.2.268

Chou, H. W., \& Wang, T. B. (2000). The Influence of Learning Style and Training Method on Self-Efficacy and Learning Performance in WWW Homepage Design Training. International Journal of Information Management, 20, 455-472. http://dx.doi.org/10.1016/S0268-4012(00)00040-2

Demirbaş, O. O., \& Demirkan, H. (2003). Focus on Architectural Design Process through Learning Styles. Design Studies, 24, 437-456. http://dx.doi.org/10.1016/S0142-694X(03)00013-9

Demirbaş, O. O., \& Demirkan, H. (2007). Learning Styles of Design Students and the Relationship of Academic Performance and Gender in Design Education. Learning and Instruction, 17, 345-359. http://dx.doi.org/10.1016/j.learninstruc.2007.02.007

Efklides, A., Papadaki, M., Papantoniou, G., \& Kiosseoglou, G. (1997). Effects of Cognitive Ability and Affect on School Mathematics Performance and Feelings of Difficulty. The American Journal of Psychology, 110, 225-258. http://dx.doi.org/10.2307/1423716

Efklides, A., Papadaki, M., Papantoniou, G., \& Kiosseoglou, G. (1999). Individual Differences in School Mathematics Performance and Feelings of Difficulty: The Effects of Cognitive Ability, Affect, Age, and Gender. European Journal of Psychology of Education, 14, 57-69. http://dx.doi.org/10.1007/BF03173111

Everson, H. T., Millsap, R. E., \& Rodriguez, C. M. (1991). Isolating Gender Differences in Test Anxiety: A Confirmatory Factor Analysis of the Test Anxiety Inventory. Educational and Psychological Measurement, 51, 243-251. http://dx.doi.org/10.1177/0013164491511024

Eysenck, M. W. (1992). Anxiety: The Cognitive Perspective. Hove: Erlbaum.

Felder, R. M., Felder, G. N., \& Dietz, E. J. (2002). The Effects of Personality Type on Engineering Student Performance and Attitudes. Journal of Engineering Education, 91, 3-17. http://dx.doi.org/10.1002/j.2168-9830.2002.tb00667.x

Gumusburun Ayalp, G., Senyigit, O., \& Erman, O. (2015). Exploring the Learning Styles Characteristics of Turkish Freshman Architecture Students Wit the Evidence of Learning Style Inventory. Journal of the Institute of Science and Technology of Balıkesir University, 17, 68-82.

Hembree, R. (1988). Correlates, Causes, Effects, and Treatment of Test Anxiety. Review of Educational Research, 58, 47-77. http://dx.doi.org/10.3102/00346543058001047

Honey, P., \& Mumford, A. (1989). The Learning Styles Questionnaire, Peter Honey Publications. www.peterhoney.com

Hong, E. (1998). Differential Stability of Individual Differences in State and Trait Test Anxiety. Learning and Individual Differences, 10, 51-69. http://dx.doi.org/10.1016/S1041-6080(99)80142-3

Hsu, C. H. C. (1999). Learning Styles of Hospitality Students: Nature or Nurture? Hospitality Management, 18, 17-30. http://dx.doi.org/10.1016/S0278-4319(98)00045-0

Ibrahim, N., \& Utaberta, N. (2012). Learning in Architecture Design Studio. Procedia-Social and Behavioral Sciences, 60, 30-35. http://dx.doi.org/10.1016/j.sbspro.2012.09.342

Jonassen, H. D., \& Grobowski, B. L. (1999). Handbook of Individual Differences, Learning and Instruction. New York: Taylor \& Francis.

Kolb, A. Y., \& Kolb, D. A. (2005). Learning Styles and Learning Spaces: Enhancing Experiential Learning in Higher Education. Academy of Management Learning \& Education, 4, 193-212. http://dx.doi.org/10.5465/AMLE.2005.17268566

Kolb, D. A. (1984). Experiential Learning: Experience as the Source of Learning and Development. Upper Saddle River, NJ: Prentice Hall.

Kolb, D. A. (1985). Learning Style Inventory: Self Scoring Test and Interpretation Booklet. Boston, MA: McBer.

Kolb, D. A. (1999). Learning Style Inventory. Boston, MA: McBer.

Kuri, N. P., \& Truzzi, M. S. (2002). Learning Styles of Freshmen Engineering Students. In Proceedings of the 2002 International Conference on Engineering Education. Arlington, VA: International Network for Engineering Education \& Research. http://citeseerx.ist.psu.edu/viewdoc/download?doi=10.1.1.12.8463\&rep=rep1\&type=pdf

Kvan, T., \& Yunyan, J. (2005). Students’ Learning Styles and Their Correlation with Performance in Architectural Design Studio. Design Studies, 26, 19-34. http://dx.doi.org/10.1016/j.destud.2004.06.004

Liebert, R. M., \& Morris, C. W. (1967). Cognitive and Emotional Components of Test Anxiety: A Distinction and Some Initial Data. Psychological Reports, 20, 975-978. http://dx.doi.org/10.2466/pr0.1967.20.3.975

Liepmann, D., Marggraf, C., Felfe, J., \& Hosemann, A. (1992). Anxiety, Action Orientation, Subjective State and Situational Aspects: A Study of Tank-Lorry Drivers. In K. Hagtvet, \& T. B. Johnson (Eds.), Advances in Test Anxiety Research (Vol. 7, pp. 130-141). Amsterdam/Lisse: Swets \& Zeitlinger.

Lowe, P. A., Lee, S. W., Witteborg, K. M., Prichard, K. W., Luhr, M. E., Cullinan, C. M., Mildren, B. A., Raad, J. M., Cornelius, R. A., \& Janik, M. (2008). The Test Anxiety Inventory for Children and Adolescents (TAICA): Examination of the 
Psychometric Properties of a New Multidimensional Measure of Test Anxiety among Elementary and Secondary School Students. Journal of Psychoeducational Assessment, 26, 215-230. http://dx.doi.org/10.1177/0734282907303760

Metallidou, P., \& Vlachou, A. (2007). Motivational Beliefs, Cognitive Engagement, and Achievement in Language and Mathematics in Elementary School Children. International Journal of Psychology, 42, 2-15. http://dx.doi.org/10.1080/00207590500411179

Nalçakan, H., \& ve Polatoğlu, Ç. (2008). Türkiye’dekive Dünyadaki Mimarlık Eğitiminin Karşılaştırmalı Analiziile Küreselleşmenin Mimarlık Eğitimine Etkisinin Irdelenmesi. Yıldız Teknik Üniversitesi, Mimarlık Fakültesi E-Dergisi, 3, 79-103.

Phillips, B. N., Martin, R. P., \& Myers, J. (1972). Interventions in Relation to Anxiety in School. In C. D. Spielberger (Ed.), Anxiety: Current Trends in Theory and Research (Vol. 2, pp. 409-468). New York: Academic Press. http://dx.doi.org/10.1016/B978-0-12-657402-9.50011-9

Rayner, S., \& Riding, R. (1997). Towards a Categorisation of Cognitive Styles and Learning Styles. Educational Psychology, 17, 5-27. http://dx.doi.org/10.1080/0144341970170101

Richardson, F. C., \& Suinn, R. M. (1972). The Mathematics Anxiety Rating Scale: Psychometric Data. Journal of Counseling Psychology, 19, 551-554. http://dx.doi.org/10.1037/h0033456

Sarason, I. G. (1984). Stress, Anxiety and Cognitive Interferences: Reactions to Tests. Journal of Abnormal and Social Psychology, 46, 929-938. http://dx.doi.org/10.1037/0022-3514.46.4.929

Smith, D. M., \& Kolb, D. A. (1996). User's Guide for the Learning-Style Inventory: A Manual for Teachers and Trainers. Boston, MA: McBer.

Spielberger, C. D. (1980). Test Anxiety Inventory: Preliminary Professional Manual. Palo Alto, CA: Consulting Psychologists Press.

Spielberger, C. D., \& Vagg, P. R. (1995). Test Anxiety: A Transactional Process Model. In C. D. Spielberger, \& P. R. Vagg (Eds.), Test Anxiety: Theory, Assessment, and Treatment (pp. 3-14). Washington DC: Taylor \& Francis.

Spielberger, C. D., Gonzalez, E. P., Taylor, C. J., Anton, W. D., Algaze, B., Ross, G. R., \& Westberry, L. G. (1979). Preliminary Manual for the Test Anxiety Inventory. Palo Alto, CA: Consulting Psychologists Press.

Spielberger, C. D., Gonzalez, H. P., Taylor, C. J., Algaze, B., \& Anton, W. D. (1978). Examination Stress and Test Anxiety. In C. D. Spielberger, \& I. G. Sarason (Eds.), Stress and Anxiety (Vol. 5, pp. 111-131). New York: Hemisphere/Wiley.

Sub, A., \& Prabha, C. (2003). Academic Performance in Relation to Perfectionism, Test Procrastination and Test Anxiety of High School Children. Psychological Studies, 48, 7-81.

Tucker, R. (2008). Learning Style Drift: Correlation between Built Environment Students' Learning Styles and the Learning Styles of Their Teachers. Journal for Education in the Built Environment, 3, 68-79. http://dx.doi.org/10.11120/jebe.2008.03010068

Van der Ploeg, H. M. (1984). Worry, Emotionality, Intelligence, and Academic Performance in Male and Female Dutch Secondary School Children. In H. M. Van der Ploeg, R. Schwarzer, \& C. D. Spielberger (Eds.), Advances in Test Anxiety Research (pp. 201-210). Hillsdale, NJ: Erlbaum.

Ware, W. B., Galassi, J. P., \& Dew, K. M. H. (1990). The Test Anxiety Inventory: A Confirmatory Factor Analysis. Anxiety Research, 3, 205-212. http://dx.doi.org/10.1080/08917779008248753

Zeidner, M. (1990). Does Test Anxiety Bias Scholastic Aptitude Test Performance by Gender and Social Group? Journal of Personality Assessment, 55, 145-160. http://dx.doi.org/10.1207/s15327752jpa5501\&2_14

Zeidner, M. (1998). Test Anxiety: The State of the Art. New York: Plenum Press.

Zeidner, M., \& Schleyer, E. J. (1999). Test Anxiety in Intellectually Gifted Students. Anxiety, Stress and Coping, 12, 163189. http://dx.doi.org/10.1080/10615809908248328 